\title{
Analysis on the Impact of Leadership to Employee Performance Considering Organizational Culture and Job Satisfaction as Mediators
}

\author{
M. Arief Riyadi \\ Universitas Indonesia, Faculty of Administrative Science \\ E-mail: arief_mubarok@yahoo.com \\ Pantius D. Soeling (Corresponding author) \\ Universitas Indonesia, Faculty of Administrative Science \\ E-mail: pantiusdrahen@gmail.com
}

Received: Nov. 11, 2019 Accepted: Dec. 11, 2019 Online published: Dec. 23, 2019

doi:10.5296/jpag.v9i4.16102ＵRL: https://doi.org/10.5296/jpag.v9i4.16102

\begin{abstract}
This paper examines organizational culture, leadership, employee performance and job satisfaction at Faculty of Humanities, Universitas Indonesia. During the two periods of the current incumbent dean leadership, there are still many unresolved problems mainly problems related to human resources quality, employee discipline, low performance and others. This situation might occur due to the absence of clear written organizational culture in the Faculty of Humanities. Based on the background above, this paper will discuss how organizational culture and job satisfaction mediate leadership and job performance in order to support the implementation of academic activities at Universitas Indonesia, especially the Faculty of Humanities. The results show that (1) leadership has positive influence on employee performance, organizational culture, and job satisfaction (2) organizational culture has positive influence on employee performance (3) job satisfaction has positive influence on employee performance (4) organizational culture becomes the mediator between leadership and employee performance (5) job satisfaction becomes the mediator between leadership and employee performance.
\end{abstract}

Keywords: leadership, employee performance, organizational culture, job satisfaction 


\section{Introduction}

\subsection{Background}

This study examines leadership, organizational culture, and employee performance at the Faculty of Humanities, Universitas Indonesia (Fakultas Ilmu Pengetahuan Budaya Universitas Indonesia- FIB UI). Universitas Indonesia and FIB UI were chosen as the research objects because according to Ministry of Research, Technology, and Higher Education in 2018, Universitas Indonesia was ranked $4^{\text {th }}$ in Indonesian tertiary institutions based on higher education performance assessment indicators such as quality of human resources, quality of institutions, quality of student activities, quality of research and community service and quality of innovation. Therefore, Universitas Indonesia should have provided good services to students professionally. However, there are still many problems found in Universitas Indonesia and FIB UI in particular.

Furthermore, FIB UI was chosen because no research has been conducted on organizational culture, leadership and employee performance in this faculty. In addition, the Dean of FIB UI was the incumbent Dean of 2 periods, so the leadership period was quite long. Currently, the head of the faculty or the Dean is Dr. Adrianus Laurens Gerung Waworuntu, S.S., M.A. He and his management (Vice Deans and Managers) are already entering the second period of his term. The first period was from 2014 to 2017, and the second period is from 2018 to 2021 .

As a public sector organization, the Faculty of Humanities, Universitas Indonesia (FIB UI) provides services to students, lecturers and the community. In order to maintain the quality and good services, employee performance evaluations are conducted regularly. Therefore, at the end of each year, FIB UI always evaluates the performance of its employees. There are several elements in conducting employee performance appraisal including disciplines, service orientation, work initiatives, work behavior and others. Regarding the elements of discipline, the following Table 1 shows the attendance of the employees of the Faculty of Humanities at the Universitas Indonesia.

Table 1. Recapitulation of Employee Attendance at the Faculty of Humanities, Universitas Indonesia, January to December 2018

\begin{tabular}{l|l}
\hline Description & Number of Employee \\
\hline Annual leave & 62 \\
\hline Permission leave & 83 \\
\hline Work leave & 50 \\
\hline Absence & 123 \\
\hline Late < 15 Minutes & 105 \\
\hline Late 16-30 Minutes & 94 \\
\hline Late > 30 Minutes & 96 \\
\hline Permission to leave early & 118 \\
\hline
\end{tabular}

Data Source: Human Resources Unit of FIB UI

Based on the data on Table 1 above, it can be seen that absence without information has the 
highest number which was 123 people in one year. The next high number of late attendance is late less than 15 minutes to late more than 30 minutes which is comprised of 295 people in one year. This shows that employee discipline in the Faculty of Humanities is still in the low category.

After the data on employee attendance are acquired, the writer also interviewed several leaders at FIB UI. Based on the data and the results of interviews with the Dean, Vice Dean I and Vice Dean II, there are still employees who have not taken the initiative to work optimally. These employees still do not have working awareness. The author tries to relate this information to the vision, missions, and organizational cultural values. One of the reasons for the lack of initiative is that there is no printed writing of the motto, vision, missions, and cultural values of the organization in FIB UI buildings so that employees have not permeated the organization's motto, vision, missions, and cultural values. The absence of written information is also in line with the absence of oral information or the inculcation of vision, missions, and organizational culture at FIB UI.

According to the results of an interview with the employee in the Human Resources Unit regarding Job Satisfaction, there is no reward system for their performance at FIB UI. A few years ago, there was an Employee of The Year Award, but the employees did not know what the indicators were. Although all regulations are derived from Universitas Indonesia, the Faculty should have a stable reward system so that it can motivate the performance of its employees. Furthermore, related to employee performance appraisal, the Heads of Unit as a direct supervisor who assesses his/her subordinates still find it difficult to make an objective assessment based on their subordinates' performance. They do not feel free to assess because the subordinate is a good friend or an older colleague. Therefore, the Head of Units gave a pretty good score even though the employee's performance results did not reach the target.

Therefore, during the two periods of the incumbent dean leadership, there are still many things that need to be resolved, such as HR quality problems, employee discipline problems, the employee low performance and others. Based on the background above, this paper will discuss organizational culture, leadership, employee performance and job satisfaction at Faculty of Humanities, Universitas Indonesia while supporting the implementation of academic activities.

\subsection{Research Problems}

Based on the background of the problem, the research problems that can be formulated in this paper are:

1. How did the Leadership of the Dean of the Faculty of Humanities, Universitas Indonesia in the 2014-2017 period affect the employee performance of the Faculty of Humanities, Universitas Indonesia?

2. How did the Leadership of the Dean of the Faculty of Humanities, Universitas Indonesia in the 2014-2017 period affect the Organizational culture of the Faculty of Humanities, Universitas Indonesia? 
3. How did the Leadership of the Dean of the Faculty of Humanities, Universitas Indonesia in the 2014-2017 period affect the Job Satisfaction of employees at the Faculty of Humanities, Universitas Indonesia?

4. How did Organizational culture affect the employee performance at Faculty of Humanities, Universitas Indonesia?

5. How did Job Satisfaction affect the employee performance at Faculty of Humanities, Universitas Indonesia?

6. How could Organizational culture mediate the leadership of Faculty of Humanities, Universitas Indonesia and the employee performance of Faculty of Humanities, Universitas Indonesia?

7. How could Job Satisfaction mediate the leadership of Faculty of Humanities, Universitas Indonesia and the employee performance of Faculty of Humanities, Universitas Indonesia.

\section{Literature Review}

\subsection{Prior Researches}

More than two decades ago, Yousef (2000) conducted a research on how commitment becomes mediator for leadership and job outcomes. He argues that job outcomes consisting of employee performance and job satisfaction could be mediated by the commitment of the leaders. Such commitment will boost employee performance and job satisfaction. Different from Yousef, Bass et al. (2003) argue that potency and cohesion are the best mediator for leadership and performance. They also argue that both transformational leadership and transactional leadership would fit in this theory. In other words, potency and cohesion could be mediator for both types of leadership and employee performance. However, they also note that there might be different outcomes for each type of leadership.

Wang et al. (2005) had different argument by stating that Leader Member Exchange (LME) mediates transformational leadership and members' performance and organizational citizenship culture. They explained that if the leader expected a certain target, then the members who met the targets would be given rewards. Such actions would certainly increase members' performance. Boerner et al. (2007) also have the variables of transformational leadership, performance and organizational citizenship culture on their research. Although Boerner et al. (2007) also use the variable of organizational citizenship culture, they argue that organizational citizenship behavior is the mediator of transformational leadership and employee performance.

Ogbonna \& Harris (2000) conducted a research on leadership, organizational culture and performance in the British Companies. They show that leadership is able to motivate the employees to work harder and better, so the employees could achieve the targets expected by the company. In other words, it has affected their performance. Besides, this research shows how cultural organization as a mediator could affect leadership style on job satisfaction which increases employee performance. 
Another case is conducted by Sumual (2015) with the title "The Effect of Leadership Competencies, Organizational culture on Employee Performance at Manado State University". This research is a quantitative research with explanatory survey method which aims to test the factual proposition of the influence of variables, namely leadership competency variables, organizational culture on employee performance. The sampling technique uses multistage sampling (gradual sampling). The analysis technique uses path analysis in order to find out how much the direct and indirect influence between leadership competency variables, organizational culture variables and employee performance variables. The result is that organizational culture and leadership competence have a very strong influence on improving employee performance at Manado State University.

In addition, there is also an article entitled "The Influence of Transformational Leadership and Work Motivation on Employee Performance Mediated by Job Satisfaction" written by Prabowo et al. (2018). The research method used is an explanatory study approach. Data collection is using primary and secondary data. Then to analyze the data, the SEM-PLS method and Sobel Test are used to test the mediation variables. This study produces the conclusion that (1). Employee performance is not significantly affected by Transformational Leadership. (2). Employee performance can be significantly influenced by work motivation. (3). Transformational leadership provides a significant influence on job satisfaction. (4). Work motivation significantly influences job satisfaction. (5). Job satisfaction significantly influences employee performance. (6). Transformational leadership if through job satisfaction has a significant influence on employee performance. (7). Work motivation through job satisfaction gives a significant effect on employee performance.

After seeing and studying previous studies and literature reviews, the authors conducted a research update that is within the scope of the Faculty of Humanities of the Universitas Indonesia with leadership variables, employee performance variables, organizational culture variables and Job Satisfaction variables. It is hoped that this research can have a positive impact in the form of improving employee performance.

\subsection{Leadership}

After making observations, this paper takes two leadership models that are most in accordance with the Dean of FIB UI, namely the theory of transformational and transactional leadership. James MacGregor Burns in his book entitled Leadership in 1978, explained two types of leadership, transactional and transformational, in detail. Transactional leadership refers to a collection of leadership models that focus on the beneficial and mutual exchanges between leaders and followers. In contrast to transactional leadership, transformational leadership focuses on the process in which people engage with others, and create relationships that increase motivation and morality in leaders and followers. This type of leader has more attention to the needs and motives of followers, and tries to help followers bring out the best potential for them.

According to Avolio \& Bass (2002), Transformational leadership does more than what was agreed with colleagues and followers. Usually they achieve maximum results using one or more of the four components. First, ideal leadership is when followers try to follow and 
emulate their leaders. Second, leadership inspires followers with challenges and persuasions that provide meaning and understanding. Third, leadership stimulates intellectually, increasing the work of followers using their abilities. And fourth, leadership gives individual consideration, provides support and guidance to followers.

People who display transformational leadership often have strong internal values and principles. They are effective in motivating followers to act in ways that support greater interests, rather than their own interests (Kuhnert in Peter G. Northouse, 1994). The Transformational Leadership factors are:

1. Ideal influence or commonly called Charisma. The charisma factor is measured on two components, namely the component of follower recognition to leaders based on the views they have of their leader, and the behavioral component which refers to follower observations of leader culture. In essence, the charisma factor describes people who are considered special and who want to make others follow the vision that they express.

2. Inspiring motivation. This factor describes leaders who communicate high expectations to followers, inspire them through motivation to be loyal and to be part of a shared vision in the organization. In practice, leaders usually use symbols and emotional appeal to focus the efforts of group members, to achieve more achievements than they would do for their personal interests so that team spirit can be increased again.

3. Intellectual stimulation. This includes leadership that stimulates followers to be more creative and more innovative and stimulates their own beliefs and values, as well as the values and beliefs of leaders and organizations. This type of leadership supports followers through persuasive approaches and develops innovative ways to deal with organizational problems. It encourages employees to be more independent and participate in careful decision making.

4. Adapted considerations. This factor represents leaders who provide a supportive climate, such as listening carefully to their individual needs followers. Here the leader acts as a trainer and advisor, trying to help followers to truly realize what they want. This leader usually uses delegation to help followers grow through personal challenges.

Transactional leadership is different from transformational leadership, because transactional leaders do not adjust the needs of followers or focus on their personal development. Transactional leaders change values with followers to develop their own programs and followers (Kuhnert in Peter G. Northouse, 1994). Transactional leaders are influential, because they care deeply about followers so that they do what the leader wants (Kuhnert \& Lewis, 1987 in Peter G. Northouse). The Transactional Leadership factors are:

1. Conditional rewards, namely the process of exchange between leaders and followers in which followers' efforts are exchanged for certain rewards. With this leadership, the leader tries to get agreement from followers about what must be done and what rewards there will be for those who do that.

2. Management by exception, means leadership which involves constructive criticism, 
negative feedback and negative encouragement. This factor has two forms, active and passive. The active form means the leader watches over the follower carefully. If the follower makes a mistake, the leader immediately takes corrective action. Passive form means the leader intervenes only after standards cannot be met or a problem has occurred.

After seeing the explanation of leadership above, the author applies the definition of Avolio \& Bass (2002) regarding Transformational Leadership along with its indicators with the consideration that the Faculty of Humanities Universitas Indonesia has a Dean who serves for two periods. The dean motivates his employees to change work patterns together that were initially less promising to be even better.

\subsection{Organizational Culture}

In some of the literature on organizational culture, almost all words for culture have the same meaning as as organizational culture. One of them is the understanding of organizational culture according to Luthans (in Safaria, 2004), defining organizational culture as a set of core values, assumptions, understandings, and ways of thinking shared by members of the organization and taught to other members.

Another case is explained by John P. Kotter and James L. Heskett (1992) who explain that organizational culture has three levels. First is organizational culture that is visible (surface). The second level, organizational culture is the level of culture that is invisible. The third level is the deepest beliefs or hidden assumptions.

According to Deddy \& Rivai (2011), culture is

"a role model of basic acceptance when found or developed by certain groups as an effort to learn to overcome the problems of external adaptation and internal integration that have worked smoothly enough to become legitimate considerations and, by therefore, to teach new members as the right way to feel, think and feel in relation to problems."

After seeing some of the theories above, the author also compares it to the organizational cultural values that exist at the Faculty of Humanities, Universitas Indonesia. Previously, it was also explained by the Dean of the Faculty of Humanities, Universitas Indonesia that FIB UI does not have its own cultural motto. However, it was further said that the FIB organizational culture motto followed the motto at the Universitas Indonesia, namely Veritas, Probitas and Iustitia (true, honest and fair). In connection with the UI motto, at the end of 2018, the UI rector issued a Rector's Decree Number 2719 / SK / R / UI / 2018 concerning Determination of Key Cultural Indicators of Universitas Indonesia's Cultural Values. In the Rector's Decree it was explained that to implement the values of the UI culture, identification, proposed transformation, and implementation of key cultural indicators of cultural values based on UI regulations. The nine UI cultural values are honesty, fairness, trustworthiness, dignity, responsibility, togetherness, openness, academic freedom, and obedience to the rules.

\subsection{Employee Performance}

According to Herman Aquinis in his book entitled Performance Management in 2012, performance is about behavior or what employees do, not what has been produced by them. 
There are two additional characteristics of performance behavior. First, they are evaluative which means that behavior can be judged negative, neutral or positive. In other words, the value of these behaviors are based on whether they contribute to the achievement of individual, unit and organizational goals. Second is multidimensional performance. This means that there are many types of behavior that have the capacity to advance (or hinder) organizational goals.

The same opinion was expressed by Armstrong (2006) which states that performance is defined not from what is produced but how they achieve it. Furthermore Armstrong (2006) explains that performance management is a planned process whose main elements are agreement, measurement, feedback, positive assistance and dialogue. In this case performance management focuses on targets, standards and measures or performance indicators. Performance management indicators according to Armstrong are

1. Concern for outputs, outcomes, processes and inputs. Performance management that cares about achieving results and the impacts they make. Also pay attention to the processes needed to achieve current results and inputs in terms of abilities such as knowledge, skills and competencies.

2. Concern for planning. This means that performance management is very concerned about planning ahead to achieve success in the future.

3. Concern for measurement and review. Performance management is very concerned about the results of measurements and reviewing the ability to achieve organizational goals.

4. Concern for continuous improvement. Improvements are based on a belief that continues to strive to achieve higher standards.

5. Concern for sustainable development. It means integrating learning and work so that everyone learns from the successes and challenges inherent in daily activities.

6. Concern for communication. Performance management can create a climate of continuous dialogue between managers and members of the organization.

7. Concern for stakeholders. Performance management is expected to meet all the needs and expectations of all stakeholders.

8. Concern for justice and transparency

\subsection{Job Satisfaction}

According to Fred Luthans (2011) in his book titled Organizational Behavior: An Evidence-Based Approach, Job Satisfaction is the result of employees' perceptions of how well they do work that is seen as important. In general, Job Satisfaction is an important and often learned attitude of employees. Furthermore, Luthans explains the characteristics of Job Satisfaction:

1. The work itself, the extent to which the work provides interesting things such as opportunities for learning and opportunities to accept responsibility; 
2. Salary, the amount of financial remuneration received and the extent to which this is deemed equivalent to the abilities of others in the organization;

3. Promotion opportunities, opportunities to enhance careers in organizations;

4. Supervision or supervision, the ability of supervisors to provide technical assistance and moral assistance;

5. Co-workers, the extent to which fellow workers are technically mutually supportive.

Meanwhile according to Robbins \& Judge (2018),

"When people speak of employee attitudes, they usually mean job satisfaction, which describes a positive feeling about a job, resulting from an evaluation of its characteristics. A person with a high level of job satisfaction holds positive feelings about his or her job, whereas a person with a low level holds negative feelings ". This means that when people talk about employee behavior, it usually means job satisfaction, which is a picture of positive feelings towards work, the result of evaluating the employee's character. Someone with a high level of job satisfaction has positive feelings about their work, while people with low levels have negative feelings.

As for the indicators of Job Satisfaction, Robbin and Judge also mentioned the same indicators as Luthans, such as the job itself, rewards, supervision, co-workers and promotional opportunities.

Another research is conducted by Weiss et al. (1967) from the University of Minnesota. They created a measurement tool to measure a person's Job Satisfaction against his work called The Minnesota Satisfaction Questionnaire (MSQ). MSQ provides more specific information about aspects of work that one thinks are valued rather than taking more general measures of job satisfaction. MSQ has two ways namely The Long-form MSQ and The Short-form MSQ. The indicators for The Short-form MSQ are 3 scales, namely Intrinsic Satisfaction, Extrinsic Satisfaction and General Satisfaction. Whereas the measurement indicators for The Long-form MSQ are as follows:

1. Ability utilization;

2. Achievement or award;

3. Activity;

4. Advancement or progress;

5. Authority;

6. Company policies and practices;

7. Compensation or compensation;

8. Co-workers or colleagues;

9. Creativity; 
10. Independence or freedom;

11. Moral values ;

12. Recognition

13. Responsibility;

14. Security or guarantee;

15. Social service;

16. Social or social status;

17. Supervision-human relations or supervision by superiors;

18. Supervision-technical or engineering supervision;

19. Variety or diversity;

20. Working conditions;

In addition to the researches mentioned earlier, there is also a research conducted by Nathan A. Bowling together with Gregory D. Hammond. Together, they made a study entitled "A meta-analytic examination of the construct validity of the Michigan Organizational Assessment Questionnaire Job Satisfaction Subscale". As stated by Wright in Bowling \& Hammond (2008), research on Job Satisfaction has a fairly long history in the field of industrial and organizational psychology where Job satisfaction has often been used as a potential, correlated, and has consequences related to work and non-work variables work. Variable- Michigan Organizational Assessment Questionnaire Job Satisfaction Subscale or commonly expressed MOAQ-JSS was developed as an alternative to the Job Diagnostic Survey (JDS) (Hackman \& Oldham in Bowling \& Hammond, 2008) and included indicators of the variable. This variable includes a description of the work environment (job characteristics), psychological statements (meaningful experiences and feelings of responsibility), and responses from employees (Job Satisfaction and motivation). There are three indicators of MOAQ-JSS, namely: "Overall I am satisfied with my work", "In general I do not like my work", and "Overall I like my work here".

This paper uses Job Satisfaction measurements using MOAQ-JSS. One of the advantages of MOAQ-JSS is the consistency of just three indicators, while the Job Satisfaction measurement tool in general is too long, for example the Job Description Index has 72 indicators, while the long-form and short-form of The Minnesota Satisfaction Questionnaire (MSQ) has 100 indicators and 20 indicators. Another advantage of MOAQ-JSS is a valid measurement in calculating the affective component of job satisfaction. This is very important because the definition of Job Satisfaction generally describes it as an affective or emotional component. Job Satisfaction can be said that not only relates to the mind but also relates to feelings about the work itself. From each indicator the overall question "I am satisfied with my work", "in general I do not like my work", and "overall I like my work here" produces answers "satisfied, dissatisfied, like or dislike "Can describe words that are 


\section{Macrothink}

Journal of Public Administration and Governance

ISSN 2161-7104 2019, Vol. 9, No. 4

affective or emotionally oriented. So MOAQ-JSS can be very useful when there are concerns about the large number of questionnaires making the Job Satisfaction measure longer and cumbersome.

\subsection{Analysis Model}

The analysis model in this study consists of:

a. Independent Variable: Leadership

b. Bound Variable: Employee Performance

c. Mediator Variables: Organizational culture and Job Satisfaction

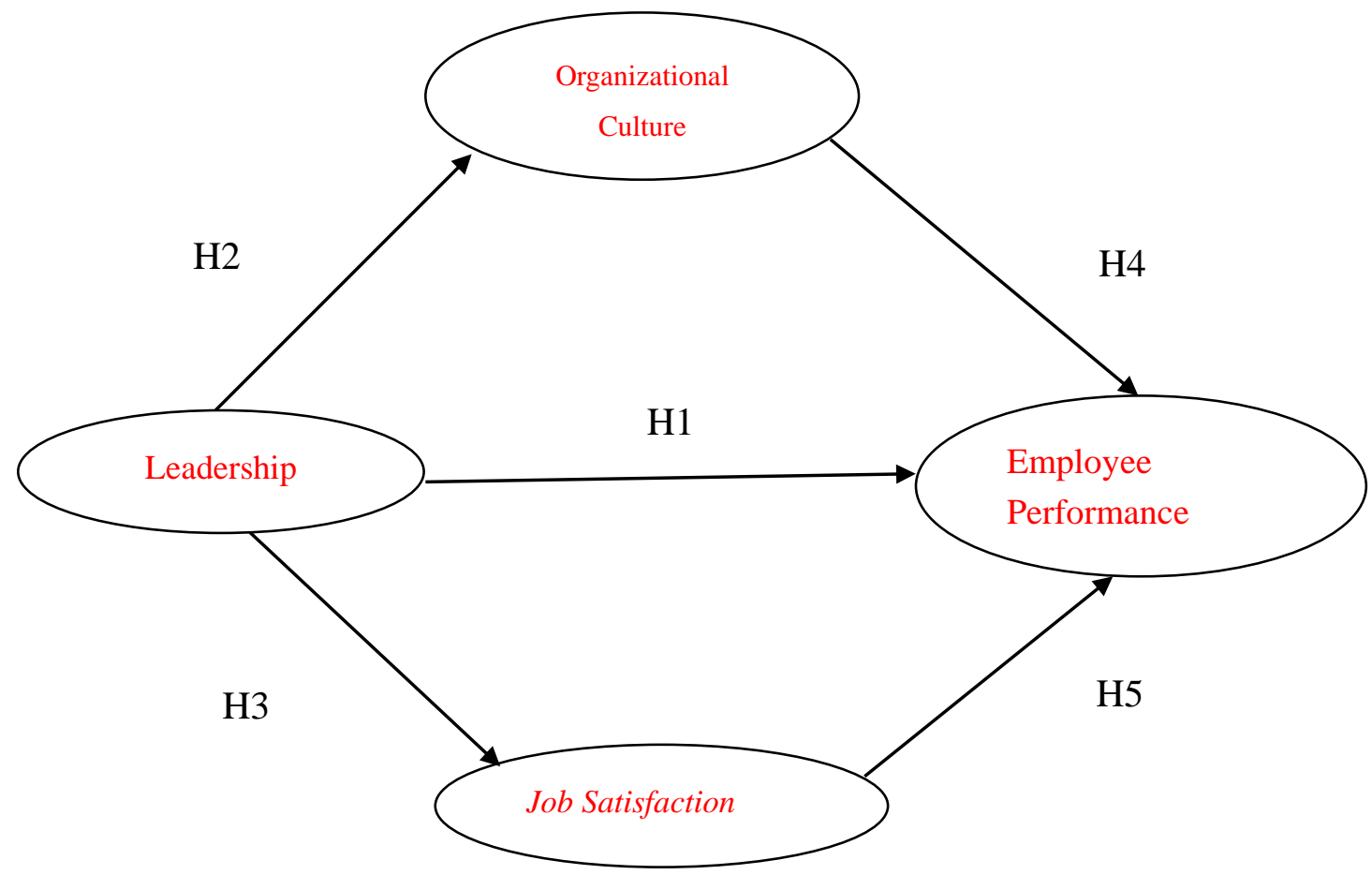

\subsection{Hypothesis}

The hypotheses in this study are as follows:

H1: Leadership has a positive effect on employee performance

H2: Leadership has a positive effect on Organizational culture

H3: Leadership has a positive effect on Job Satisfaction

H4: Organizational culture has a positive effect on Employee Performance

H5: Job Satisfaction has a positive effect on Employee Performance

H6: Organizational culture becomes a mediator between Leadership and Employee Performance

H7: Job Satisfaction becomes a mediator between Leadership and Employee Performance 


\section{Research Methodology}

Based on the characteristics of the problems in this study that is the effect of leadership on employee performance with organizational culture as a mediator at the Faculty of Humanities, Universitas Indonesia, the authors use positivism research with quantitative data collection methods. There are some indicators of variables or dimensions derived from several theories on organizational leadership, performance and organizational culture. The researcher uses a deductive perspective, which starts from the process of observation, hypothesis, collecting data, testing the hypothesis, and the final step drawing conclusions.

In the research stage, the researcher begins by collecting a literature study that is in accordance with the research title, which is about leadership, performance and organizational culture. After the researcher collects the literature study, the researcher conducts an interview to identify the existing problem. The initial informants are the Dean of the Faculty of Humanities, Universitas Indonesia and the employees who are working under his leadership. Based on the results of the interview, the researcher makes a questionnaire that would be distributed to permanent employees at the Faculty of Humanities, Universitas Indonesia. The questionnaire aims to explore / verify / find solutions / draw conclusions. In the data analysis stage, the researcher analyzes the value obtained in the questionnaire in an SPSS software. The data collected will be interpreted by referring to the existing theories and literature studies.

Various data and information are collected first hand. First, researcher looks for data through literature studies. The next data come from the interview questions that have been asked to the subjects of research. Meanwhile, the main data is the result of a questionnaire conducted by FIB UI. The instrument is in the form of a questionnaire with a total of 57 questions.

Data processing activities are as follows:

1. Structuring the raw data: the researcher organizes raw data from the field.

2. Editing data: the researcher conducts preliminary research on the data; to make sure that the data does not contain errors or defects; whether there is a questionnaire that was incorrectly filled by respondents; whether there are pages that are missing or points missed.

3. Coding: researcher classifies the answers of respondents by marking each particular code, namely with a numeric code.

The population in this study are employees who are working permanently in the Faculty of Humanities, Universitas Indonesia. The number of population in this study is 103 permanent employees. Meanwhile, data analysis is using simple regression analysis and Path Analysis. This technique is used to determine the causal relationship by determining how much influence the independent variable has on the dependent variable. Meanwhile, to measure mediating variables, writer uses Sobel test. This test is used to measure the power of the indirect influence from independent variables to dependent variables through intervening variables.

Reliability is a tool to measure a questionnaire which is an indicator of variables. A 
questionnaire is said to be reliable if a person's answer to a question is consistent or stable. A questionnaire is said to be reliable if the value of Alpha $(\alpha) \geq 0.6$. In carrying out this reliability test, the IBM SPSS 24 statistical program tool is used. Based on the reliability, testing results will be obtained which indicate that the alpha magnitude of each variable is greater than 0.6 , so all the question variables used in this study are reliable.

Validity Test is used to measure the validity of a questionnaire. A questionnaire is said to be valid or valid if the questions on the questionnaire are able to reveal something that will be measured by the questionnaire. A questionnaire is said to be valid if the correlation value ( $\mathrm{r}$ count) $>r$ table. An instrument is said to be valid if the error probability level (sig) $\leq 0.05$ and $r$ arithmetic $>r$ table, otherwise an instrument is said to be invalid if the error probability level $(\mathrm{sig}) \geq 0.05$ and $\mathrm{r}$ counting $<\mathrm{r}$ table or correlation value $(\mathrm{r}) \geq 0.6$. Calculating this validity, researchers conducted using the SPSS statistical program.

\section{Research Result}

Data are obtained from the Human Resources Unit, Faculty of Humanities, Universitas Indonesia in 2019. The faculty has 103 permanent employees with a composition of 18 Civil Servants and 85 PUI (Universitas Indonesia Employees).

After the writer made and distributed the questionnaire directly to 103 permanent employees of the Faculty of Humanities, Universitas Indonesia, only 98 employees returned the completed questionnaires. The following is a recapitulation table for respondent characteristics:

Table 2. Data Based on Employees Age

\begin{tabular}{|c|c|c|c|c|c|}
\hline & & Frequency & Percent & Valid Percent & $\begin{array}{l}\text { Cumulative } \\
\text { Percent }\end{array}$ \\
\hline \multirow[t]{7}{*}{ Valid } & 25-30 Years & 1 & 1,0 & 1,0 & 1,0 \\
\hline & 31-35 Years & 6 & 6,1 & 6,1 & 7,1 \\
\hline & 36-40 Years & 17 & 17,3 & 17,3 & 24,5 \\
\hline & 41-45 Years & 15 & 15,3 & 15,3 & 39,8 \\
\hline & 46-50 Years & 26 & 26,5 & 26,5 & 66,3 \\
\hline & 51-60 Years & 33 & 33,7 & 33,7 & 100,0 \\
\hline & Total & 98 & 100,0 & 100,0 & \\
\hline
\end{tabular}


It is explained in the Table 2 above that the age of the respondent starts from the age of 25-30 years which is 1 person, age 31-35 years which are 6 people, age 36-40 years which are 17 people, age 41-45 years which are 15 people, age $46-50$ years which are 26 people, and age 51-60 years which are 33 people.

Table 3. Data Based on Employees Sex

Sex

\begin{tabular}{|c|c|c|c|c|c|}
\hline & & Frequency & Percent & Valid Percent & $\begin{array}{l}\text { Cumulative } \\
\text { Percent }\end{array}$ \\
\hline \multirow[t]{3}{*}{ Valid } & Male & 72 & 73,5 & 73,5 & 73,5 \\
\hline & Female & 26 & 26,5 & 26,5 & 100,0 \\
\hline & Total & 98 & 100,0 & 100,0 & \\
\hline
\end{tabular}

The number of 98 respondents who returned the questionnaire consisted of 72 male employees and 26 female employees.

Table 4. Data Based on Employees Education

\section{Education}

\begin{tabular}{lll|l|l|l}
\hline & Frequency & Percent & $\begin{array}{l}\text { Valid } \\
\text { Percent }\end{array}$ & $\begin{array}{l}\text { Cumulative } \\
\text { Percent }\end{array}$ \\
\hline Valid & JHS & 1 & 1,0 & 1,0 & 1,0 \\
\cline { 2 - 5 } & SHS & 60 & 61,2 & 61,2 & 62,2 \\
\hline \begin{tabular}{l} 
Diploma \\
\hline Bachelor
\end{tabular} & 1 & 1,0 & 1,0 & 63,3 \\
\hline \begin{tabular}{l} 
Master \\
\hline
\end{tabular} & 33 & 33,7 & 33,7 & 96,9 \\
\hline Total & 98 & 3,1 & 3,1 & 100,0 \\
\hline
\end{tabular}

For the characteristics of education, ninety eight respondents have diverse backgrounds, namely the Junior High School level 1 person, the Senior High School level 60 people, the Diploma level 1 person, the Bachelor level 33 people and the Master level 3 people. 
Table 5. Data Based on Employees Status

\section{Status}

\begin{tabular}{lll|l|l|l}
\hline & Frequency & Percent & Valid Percent & Cumulative Percent \\
\hline Valid & PNS & 16 & 16,3 & 16,3 & 16,3 \\
\cline { 2 - 5 } & PUI & 82 & 83,7 & 83,7 & 100,0 \\
\hline & 98 & 100,0 & 100,0 & \\
\hline
\end{tabular}

Researcher at the Faculty of Humanities, Universitas Indonesia only took samples of Civil Services (PNS) and PUI (Universitas Indonesia Employees). Of the 98 respondents, 16 of them are civil servants and the remaining 82 are PUI.

\subsection{Validity and Reliability Test Results}

Validity test is used to determine whether the items in the questionnaire are feasible or not feasible. Testing is done with the criteria if $r$ count (corrected item total correlation) $>r$ table, then the item question tested is valid. If $r$ count (corrected item total correlation) $<r$ table, then the item question tested is invalid.

Samples taken as many as 25 so that the value of $r$ table 0.396 . If the value of rxy>0.396 is valid. However, if the value of rxy $<0.396$ then the questionnaire items were declared null and void.

Table 6. Data Based on Validity Test

\begin{tabular}{|c|c|c|c|c|}
\hline Variable & Item & R Count & R Table & Description \\
\hline \multirow{4}{*}{$\begin{array}{c}\text { Leaders } \\
\text { hip }\end{array}$} & KP1 & 0,518 & 0,396 & Valid \\
\cline { 2 - 5 } & KP2 & 0,473 & 0,396 & Valid \\
\cline { 2 - 5 } & KP3 & 0,773 & 0,396 & Valid \\
\cline { 2 - 5 } & KP5 & 0,633 & 0,396 & Valid \\
\cline { 2 - 5 } & KP6 & 0,766 & 0,396 & Valid \\
\cline { 2 - 5 } & KP7 & 0,505 & 0,396 & Valid \\
\hline
\end{tabular}




\begin{tabular}{|c|c|c|c|c|}
\hline & KP8 & 0,785 & 0,396 & Valid \\
\hline & KP9 & 0,743 & 0,396 & Valid \\
\hline & KP10 & 0,763 & 0,396 & Valid \\
\hline & KP11 & 0,693 & 0,396 & Valid \\
\hline & KP12 & 0,815 & 0,396 & Valid \\
\hline & KP13 & 0,68 & 0,396 & Valid \\
\hline & KP14 & 0,762 & 0,396 & Valid \\
\hline & KP15 & 0,69 & 0,396 & Valid \\
\hline & KP16 & 0,855 & 0,396 & Valid \\
\hline & KP17 & 0,803 & 0,396 & Valid \\
\hline & KP18 & 0,8 & 0,396 & Valid \\
\hline & KP19 & 0,866 & 0,396 & Valid \\
\hline & KP20 & 0,844 & 0,396 & Valid \\
\hline & KN1 & 0,896 & 0,396 & Valid \\
\hline & KN2 & 0,864 & 0,396 & Valid \\
\hline & KN3 & 0,833 & 0,396 & Valid \\
\hline Perform & KN4 & 0,766 & 0,396 & Valid \\
\hline & KN5 & 0,852 & 0,396 & Valid \\
\hline & KN6 & 0,862 & 0,396 & Valid \\
\hline & KN7 & 0,55 & 0,396 & Valid \\
\hline & KN8 & 0,673 & 0,396 & Valid \\
\hline
\end{tabular}




\begin{tabular}{|c|c|c|c|c|}
\hline & KN9 & 0,762 & 0,396 & Valid \\
\hline \multirow{20}{*}{$\begin{array}{c}\text { Organiz } \\
\text { ational } \\
\text { culture }\end{array}$} & BO1 & 0,7 & 0,396 & Valid \\
\hline & BO2 & 0,553 & 0,396 & Valid \\
\hline & BO3 & 0,697 & 0,396 & Valid \\
\hline & BO4 & 0,719 & 0,396 & Valid \\
\hline & BO5 & 0,741 & 0,396 & Valid \\
\hline & BO6 & 0,501 & 0,396 & Valid \\
\hline & BO7 & 0,446 & 0,396 & Valid \\
\hline & BO8 & 0,678 & 0,396 & Valid \\
\hline & BO9 & 0,688 & 0,396 & Valid \\
\hline & BO10 & 0,728 & 0,396 & Valid \\
\hline & BO11 & 0,588 & 0,396 & Valid \\
\hline & BO12 & 0,556 & 0,396 & Valid \\
\hline & BO13 & 0,65 & 0,396 & Valid \\
\hline & BO14 & 0,493 & 0,396 & Valid \\
\hline & BO15 & 0,761 & 0,396 & Valid \\
\hline & BO16 & 0,538 & 0,396 & Valid \\
\hline & BO17 & 0,623 & 0,396 & Valid \\
\hline & BO18 & 0,5 & 0,396 & Valid \\
\hline & BO19 & 0,652 & 0,396 & Valid \\
\hline & & & & \\
\hline
\end{tabular}




\begin{tabular}{|c|c|c|c|c|}
\hline \multirow{5}{*}{} & BO21 & 0,416 & 0,396 & Valid \\
\cline { 2 - 5 } & BO23 & 0,537 & 0,396 & Valid \\
\cline { 2 - 5 } & BO24 & 0,42 & 0,396 & Valid \\
\cline { 2 - 5 } Job & BO25 & 0,619 & 0,396 & Valid \\
\hline ion & JS1 & 0,845 & 0,396 & Valid \\
\hline & JS2 & 0,837 & 0,396 & Valid \\
\hline & JS3 & 0,786 & 0,396 & Valid \\
\hline
\end{tabular}

Based on the results of calculations and observations in the $r$ table values obtained from sample $(\mathrm{N})$ of 25 respondents from the validity test, there are 2 items declared invalid (rxy value <0.396). While the rest are declared valid with $r$ count greater than $r$ table of 0.396 . Invalid statement items derived from Organizational culture variables namely BO20 with the statement "I provide information openly and can be justified" with $\mathrm{r}$ count of $0.303<\mathrm{r}$ table of 0.396 , and $\mathrm{BO} 22$ with the statement "I show curiosity and give ideas creative ideas to encourage innovation and / or make continuous improvements "with $\mathrm{r}$ count of $0.225<\mathrm{r}$ table of 0.396 . So the researcher continued to distribute the questionnaire only valid statements.

\subsection{Reliability}

While the reliability test is used to measure whether the items of the questionnaire statement are reliable. The criteria in a reliable test are if Alpha> 0.6 variables have reliability, and if alpha $<0.6$ then the variable has no reliability. The reliability test of this study used the Cronbach's Alpha formula. The following are the results of the reliability test:

Table 7. Reliability Result

\begin{tabular}{l|l}
\hline Variable & Cronbach's Alpha \\
\hline Leadership & 0,950 \\
\hline Performance & 0,920 \\
\hline Organizational culture & 0,908 \\
\hline Job Satisfaction & 0,718 \\
\hline
\end{tabular}

From the table above shows that all dimensions of the study variable have a high reliability that is $>0.6$. Thus all statements on the questionnaire for this study can be used. 


\subsection{Discussion}

To calculate the linear regression analysis, researchers used the SPSS program.

The following table summarizes the results of simple and multiple regression tests that have been conducted previously.

Table 8. Summary of Result

\begin{tabular}{|c|c|c|c|c|c|c|c|}
\hline $\begin{array}{l}\text { Independent } \\
\text { Variable }\end{array}$ & $\begin{array}{l}\text { Dependent } \\
\text { Variable }\end{array}$ & $\begin{array}{l}\text { Regression } \\
\text { test }\end{array}$ & $\beta$ & $\begin{array}{l}\text { Std } \\
\text { Error }\end{array}$ & $\begin{array}{l}\mathrm{t} \\
\text { Value }\end{array}$ & Sig. & Description \\
\hline Leadership & $\begin{array}{l}\text { Employee } \\
\text { Performance }\end{array}$ & Simple & 0,295 & 0,029 & 10,326 & 0,000 & $\begin{array}{l}\text { Significant } \\
\text { influence }\end{array}$ \\
\hline Leadership & $\begin{array}{l}\text { Organizational } \\
\text { Culture }\end{array}$ & Simple & 0,423 & 0,067 & 6,302 & 0,000 & $\begin{array}{l}\text { Significant } \\
\text { influence }\end{array}$ \\
\hline Leadership & $\begin{array}{l}\text { Job } \\
\text { Satisfaction }\end{array}$ & Simple & 0,082 & 0,012 & 6,903 & 0,000 & $\begin{array}{l}\text { Significant } \\
\text { influence }\end{array}$ \\
\hline $\begin{array}{l}\text { Organizational } \\
\text { Culture }\end{array}$ & $\begin{array}{l}\text { Employee } \\
\text { Performance }\end{array}$ & Simple & 0,141 & 0,040 & 3,565 & 0,001 & $\begin{array}{l}\text { Significant } \\
\text { influence }\end{array}$ \\
\hline $\begin{array}{l}\text { Job } \\
\text { Satisfaction }\end{array}$ & $\begin{array}{l}\text { Employee } \\
\text { Performance }\end{array}$ & Simple & 0,642 & 0,223 & 2,879 & 0,005 & $\begin{array}{l}\text { Significant } \\
\text { influence }\end{array}$ \\
\hline Leadership & $\begin{array}{l}\text { Employee } \\
\text { Performance }\end{array}$ & Multiple & 0,183 & 0,035 & 5,279 & 0,000 & $\begin{array}{l}\text { Significant } \\
\text { influence }\end{array}$ \\
\hline
\end{tabular}

Based on the table 8 above, the path diagram is as follows:




Based on table 8 above, it is shown that $\mathrm{t}$ value is 10.326 . Previously it was known that the value of $\mathrm{t}$ table used significance $(\alpha)=5 \%$ and degree of freedom 98 , which was 1.98552 . Therefore, $\mathrm{t}$ count (10.326) is greater than $\mathrm{t}$ table (1.98552), then $\mathrm{H} 0$ is rejected, $\mathrm{H} 1$ is accepted. Strengthened with the calculated value sig. 0,000 <significance 0.005 . It can be concluded that there is a positive and significant influence of Leadership on Performance at the Faculty of Cultural Sciences UI. The results of this study are in line with previous research which states that there is a significant relationship between Leadership and Performance.

Based on the results of the calculation of table 8 above, the p-value obtained is 0,000 and is smaller than the significance of 0.005 . While the value of $t$ arithmetic is 6.302 and is greater than $\mathrm{t}$ table (1.98552), so that the conclusion $\mathrm{H} 0$ is rejected and $\mathrm{H} 2$ is accepted. This means that there is a positive and significant influence between Leadership on Organizational Culture at the Faculty of Cultural Sciences, UI.

Based on table 8 above for the hypothesis "Leadership has a positive effect on Job Satisfaction", the results obtained are the t value is 6.903 with a significance value of 0.000 . This means the value of $t$ arithmetic $>$ table $(6.903>1,98552)$ and the significance value of the calculation $<\alpha=0.05(0,000<0.005)$, then $\mathrm{H} 0$ is rejected and H3 is accepted. It can be concluded that leadership significantly and positively influences Job Satisfaction.

Based on the calculation of table 8 above, it can be seen that the calculated t value of the organizational culture of employee performance is 3.565 with a significance of 0.001 . Thus it can be said that $\mathrm{H} 0$ is rejected and $\mathrm{H} 4$ is accepted. This is due to the value of $\mathrm{t}$ count $>\mathrm{t}$ table and the value of sig. count $<0.05$. So it can be concluded that Organizational Culture has a significant positive effect on Employee Performance.

Based on the results of the previous table 8 calculations, it is known that the calculated $t$ value and the calculated significance value, namely the calculated t value of 2.879 and the sig value. count 0.005 . Thus the $t$ value $>t$ table value and sig value, calculate <alpha value 0.05 . Based on this value, $\mathrm{H} 0$ is rejected and $\mathrm{H} 1$ is accepted, which means there is a positive and significant influence between Job Satisfaction on Employee Performance

As for the Sobel test, the following is a summary of the calculations

\begin{tabular}{|l|l|l|l|}
\hline Intervening Variable & Sobel Test Statistic & Std. Error & p-value \\
\hline Organizational culture & 3,077 & 0,0193 & 0,002 \\
\hline Job Satisfaction & 2,653 & 0,0198 & 0,007 \\
\hline
\end{tabular}

Based on the table above, it can be concluded that the value of the indirect influence of Organizational Culture variables on employee performance is stronger than the value of the indirect effect of the Job Satisfaction variable on Employee Performance. This can be seen from the sobel test statistic of Organizational Culture variable of 3.077> Job satisfaction variable of 2.653 . 


\section{Conclusion}

Every research has a goal to answer all the formulations of the problems that have been raised at the beginning. Based on the results of the analysis that has been done, the researcher can draw conclusions as follows:

1. Leadership in Faculty of Humanities Universitas Indonesia (FIB UI) has a positive and significant influence on Employee Performance. It shows that the higher the Leadership value, the higher the Performance of FIB UI's Employees.

2. Leadership in Faculty of Humanities Universitas Indonesia (FIB UI) has a significant influence on Organizational Culture in FIB UI with a positive direction. This is shown that the higher the value of the Leadership in FIB UI, the stronger the value of Organizational Culture at FIB UI.

3. Leadership in Faculty of Humanities Universitas Indonesia (FIB UI) can positively and significantly affect the Job Satisfaction of employees at FIB UI. This means that the higher the value of the Leadership Dean of FIB UI, the higher the value of the Job Satisfaction employee at FIB UI.

4. Organizational Culture influences positively and significantly on employee performance at in Faculty of Humanities Universitas Indonesia (FIB UI). This is indicated by the greater value of Organizational Culture, the stronger the value of Employee Performance at FIB UI.

5. Job Satisfaction can affect positively and significantly on the performance of in Faculty of Humanities Universitas Indonesia (FIB UI) employees. This is indicated by the higher value of Job Satisfaction, the higher the value of the Performance of the FIB UI employees.

6. Organizational Culture can be a mediator used by the leaders in Faculty of Humanities Universitas Indonesia (FIB UI) in influencing the performance of the FIB UI.

7. Job Satisfaction can be a mediator used by the leaders in Faculty of Humanities Universitas Indonesia (FIB UI) in influencing the performance of the employees of FIB UI.

Based on the above points, further research can be carried on two important points. First, further research can focus on organizational culture that has been implanted since July 2019. Thus, the effectiveness of instilling organizational culture in employee performance can be seen. Second, other research can see how the new leadership style in the next two years affects employee performance. This can be seen whether there is transfer of knowledge from the previous leader to the next leader. In addition, employee performance during the period of new leaders can also be analyzed to measure the adaptation of leadership style to employee performance. If employee performance deteriorates, the leadership style, organizational culture, and job satisfaction in the future need to be analyzed again to find gaps with the leadership style, organizational culture, and job satisfaction this year. That way, research results can be seen on an ongoing basis and provide valuable input in the repertoire of knowledge, especially related to leadership style, organizational culture, employee performance, and job satisfaction. 


\section{References}

Aguinis, H. (2012). Performance management. Upper Saddle River, NJ: Pearson Prentice Hall.

Armstrong, M. (2006). A Handbook of Human Resource Management Practice. Kogan Page Publishers.

Avolio, B. J., \& Bass, B. M. (2002). Manual for the Multifactor Leadership Questionnaire (Form 5X).

Bass, B. M., Avolio, B. J., Jung, D. I., \& Berson, Y. (2003). Predicting unit performance by assessing transformational and transactional leadership. Journal of applied psychology, 88(2), 207. https://doi.org/10.1037/0021-9010.88.2.207

Boerner, S., Eisenbeiss, S. A., \& Griesser, D. (2007). Follower behavior and organizational performance: The impact of transformational leaders. Journal of Leadership \& Organizational Studies, 13(3), 15-26. https://doi.org/10.1177/10717919070130030201

Bowling, N. A., \& Hammond, G. D. (2008). A meta-analytic examination of the construct validity of the Michigan Organizational Assessment Questionnaire Job Satisfaction Subscale. Journal of Vocational Behavior, 73(1), 63-77. https://doi.org/10.1016/j.jvb.2008.01.004

Cahyono, A. (2012). Analisa Pengaruh Leaderhsip, Motivasi dan Organizational behavior Terhadap Kinerja Dosen dan Karyawan di Universitas Pawyatan Daha Kediri. Jurnal Ilmu Manajemen, Revitalisasi, 1(1), 283-298.

Deddy, M., \& Rivai, V. (2011). Leaderhsip dan Perilaku organisasi. Jakarta: Raja Wali Pers.

Heskett, J. L., \& Kotter, J. P. (1992). Corporate culture and performance. Business Review, 2(5), 83-93.

Luthans, F. (2011). Organizational behavior an evidence-based approach 12th edition. McGrawHill Irwin. Fq, 141.

Northouse, P. G. (1994). Introduction to leadership: Concepts and practice. Sage Publications.

Ogbonna, E., \& Harris, L. C. (2000). Leadership style, Organizational Behavior and performance: empirical evidence from UK companies. International Journal of Human Resource Management, 11(4), 766-788. https://doi.org/10.1080/09585190050075114

Prabowo, T. S., Noermijati, N., \& Irawanto, D. W. (2018). The Influence of Transformational Leadership and Work Motivation on Employee Performance Mediated By Job Satisfaction. Jurnal Aplikasi Manajemen, 16(1), 171-178. https://doi.org/10.21776/ub.jam.2018.016.01.20

Robbins, S. P., \& Judge, T. A. (2001). Organizational behavior, 14/E. E: Pearson Education India.

Safaria, T. (1995). Kepemimpinan. Yogyakarta: Graha Ilmu. 
Sumual, T. E. (2015). Pengaruh Kompetensi Leaderhsip, Organizational behavior terhadap Kinerja Pegawai di Universitas Negeri Manado. MIMBAR: Jurnal Sosial dan Pembangunan, 31(1), 71-80. https://doi.org/10.29313/mimbar.v31i1.1296

Wang, H., Law, K. S., Hackett, R. D., Wang, D., \& Chen, Z. X. (2005). Leader-member exchange as a mediator of the relationship between transformational leadership and followers' performance and organizational citizenship behavior. Academy of management Journal, 48(3), 420-432. https://doi.org/10.5465/amj.2005.17407908

Weiss, D. J., Dawis, R. V., England, G. W., \& Lofquist, L. H. (1967). Manual for the Minnesota satisfaction questionnaire, University of Minnesota. Industrial Relations Center. https://doi.org/10.1037/t08880-000

Yousef, D. A. (2000). Organizational commitment: A mediator of the relationships of leadership behavior with job satisfaction and performance in a non-western country. Journal of managerial Psychology, 15(1), 6-24. https://doi.org/10.1108/02683940010305270

Budiman, M. (2018, December 12). Interview by M. Arief Riyadi [Tape recording]. Personal Archive, Depok, West Java.

Anggari, A. (2019, January 1). Interview by M. Arief Riyadi [Tape recording]. Personal Archive, Depok, West Java.

Gustinelly, E. (2019, January 2). Interview by M. Arief Riyadi [Tape recording]. Personal Archive, Depok, West Java.

Marwoto, I. (2019, January 7). Interview by M. Arief Riyadi [Tape recording]. Personal Archive, Depok, West Java.

Waworuntu, A. L. G. (2019, January 30). Interview by M. Arief Riyadi [Tape recording]. Personal Archive, Depok, West Java.

\section{Copyright Disclaimer}

Copyright for this article is retained by the author(s), with first publication rights granted to the journal.

This is an open-access article distributed under the terms and conditions of the Creative Commons Attribution license (http://creativecommons.org/licenses/by/4.0/). 